Ethnicity without Groups 



\section{Ethnicity without Groups}

ROGERS BRUBAKER

HARVARD UNIVERSITY PRESS

Cambridge, Massachusetts, and London, England 
Copyright (C) 2004 by the President and Fellows of Harvard College All rights reserved

Printed in the United States of America

First Harvard University Press paperback edition, 2006

\section{Library of Congress Cataloging-in-Publication Data}

Brubaker, Rogers, 1956-

Ethnicity without groups / Rogers Brubaker.

p. $\mathrm{cm}$

Includes bibliographical references and index.

ISBN13 978-0-674-01539-5 (cloth)

ISBN10 0-674-01539-8 (cloth)

ISBN13 978-0-674-02231-7 (pbk.)

ISBN10 0-674-02231-9 (pbk.)

1. Ethnicity. 2. Assimilation (Sociology) 3. Nationalism. 4. Ethnic conflict.

5. Cognition and culture. I. Title.

GN495.6.B77 2004

305.8—dc22 2004047343 
For Benjamin and Daniel 
